\title{
Imagens do destino Douro em guias turísticos da segunda metade do século XX à atualidade ${ }^{1}$ Olinda Santana* Veronika Joukes** \\ Universidade de Trás-os-Montes e Alto Douro (Portugal)
}

\begin{abstract}
Resumo: Fez-se uma análise documental e discursiva dum corpus de guias turísticos publicados em Portugal de meados do século XX aos inícios do século XXI, com o objetivo de averiguar quais as imagens projetadas do Alto Douro Vinhateiro no referido género discursivo. A análise do discurso e da imagem de 22 guias permitiu concluir que a maior parte dos guias turísticos publicados antes da consagração do Alto Douro Vinhateiro a património da humanidade na categoria de paisagem cultural "evolutiva e viva", em dezembro de 2001, apresenta tão-só uma imagem projetada do destino Douro "tradicional", apoiada apenas nas referenciações materiais do território vinhateiro, entre outros, nos discursos dos guias. As mudanças político-estratégicas centrais, após a outorga da chancela Unesco ao Alto Douro Vinhateiro, com a criação duma Estrutura de Missão para o Douro (2006) e duma entidade Regional de Turismo do Polo de Desenvolvimento Turístico do Douro, em 2008, tiveram repercussões positivas nas imagens "para venda" e "promocionais" do destino, refletidas no tipo discursivo estudado, por exemplo, nos roteiros. Alguns destes últimos guias surgiram de iniciativas colaborativas das mencionadas duas entidades regionais de desenvolvimento turístico do Douro, sediadas no próprio território, e promotoras duma imagem do destino baseada em representações dos "atributos" tangíveis e intangíveis, conjugando as componentes "cognitiva" e "afetiva" propostas do território vinhateiro.
\end{abstract}

Palavras-chave: Discurso; Representação; Imagem; Guia turístico; Douro.

Images of the Douro destination in tourist guides from the second half of the twentieth century to the present

\begin{abstract}
We did a documentary and discursive analysis of a corpus of tourist guides published in Portugal from the mid - 20th century to the beginning of the 21st century, with the objective of ascertaining the projected images of the Alto Douro Vinhateiro in this discursive genre. The analysis of the discourse and image of 22 guides allowed us to conclude that most of the tourist guides published prior to the inscription of the Alto Douro Vinhateiro on the list of heritage of humanity in the category of "evolving and living" cultural landscape, in December 2001, only present a projected image of the "traditional" Douro destination, merely based on the tangible characteristics of the vineyard territory, among others in the discourses of the guides. The political-strategic changes, after the Alto Douro Wine Region was awarded the world heritage tag by UNESCO, with the creation of the Mission Structure for the Douro (2006) and the Pole of Tourism Development of the Douro, in 2008, had positive repercussions on the images created to sell and promote the destination and on the accompanying discursive style, for example, in the guides. Some of these last books resulted from collaborative initiatives of the two regional tourism entities of the Douro, and promote a projected image of the destination based not only on tangible "attributes", but also on emotions and affections triggered by the enjoyment of the terroir.
\end{abstract}

Keywords: Discourse; Representation; Image; Tourist guide; Douro.

\section{Introdução}

Partimos das conclusões de dois trabalhos sobre a "imagem turística do Alto Douro" em guias de viagem estrangeiros do século XIX (Fernandes, Vieira \& Rodrigues, 2016) e XX, mais precisamente,

\footnotetext{
* Universidade de Trás-os-Montes e Alto Douro; E-mail: osantana61@hotmail.com

** Universidade de Trás-os-Montes e Alto Douro: E-mail: veronika@utad.pt
} 
publicados de 1845 a 1974 (Fernandes, 2016), nos quais as autoras consideram que a imagem projetada nesses guias de viagem é "tradicional" e devedora da imagem construída por Joseph James Forrester (1809-1861) sobre o "Paiz Vinhateiro" (Fernandes, 2016).

Quisemos verificar se, no corpus constituído por 22 guias turísticos editados em suporte papel, em Portugal, durante cerca de 70 anos, mais precisamente de 1941 a 2013, encontrávamos as mesmas "formas específicas de ver" (Sarmento, 2004) o destino turístico Douro ou diferentes formas.

Metodologicamente, começamos por definir o género discursivo (Bakhtin, 1984) eleito. Num segundo momento, com o intuito de proceder a uma breve análise discursiva (Camlong, 1984; Fonseca, 1994) do corpus constituído, procuramos verificar algumas propostas apresentadas para o espaço Douro² (Mapa 1).

\section{Mapa 1: Alto Douro Vinhateiro Património da Humanidade 2001}

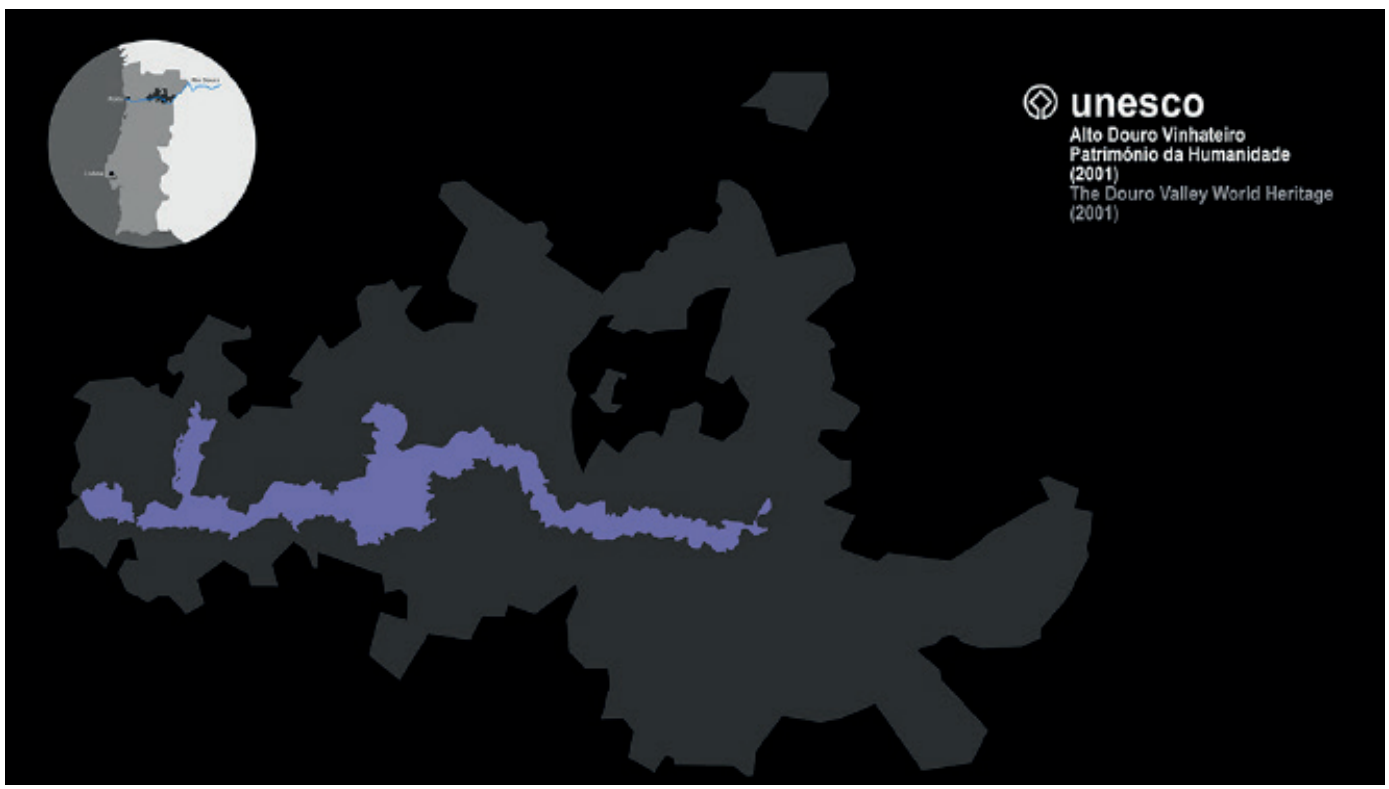

Créditos Museu do Douro

Com o tipo de metodologia escolhida, quisemos responder à seguinte hipótese de partida:

- os discursos (Camlong, 1984) dos guias turísticos selecionados evidenciam "certas práticas espaciais que resultam em formas específicas de ver a paisagem”? (Sarmento, 2004)

Examinámos um conjunto de guias com o objetivo de comprovar se as "práticas espaciais" promovidas nos discursos (Camlong, 1984) construídos nesses materiais influenciaram os olhares turísticos sobre o território duriense no período cronológico considerado.

Consideramos importante analisar este género discursivo (Bakhtin, 1984), porque, na atualidade, apesar de existirem múltiplas formas digitais com informações sobre os vários destinos turísticos disponíveis, esses assuntos estão dispersos por inúmeras páginas, exigindo uma organização por parte do viajante. Por isso mesmo muitos turistas continuam a preferir consumir este tipo de materiais, uma vez que, nestas obras, encontram os possíveis programas da viagem devidamente organizados, hierarquizados, "arrumados" por país, região ou local (Cordeiro, 2017).

\section{O género discursivo escolhido: o guia turístico}

Um guia turístico, numa perspetiva discursiva (Camlong, 1984), é uma obra técnica, utilitária destinada a preparar uma viagem. A maior parte das vezes tem um autor material, a pessoa que escreve o texto, o escrevente (Barthes, 1977, p. 205-215), que imprime o seu ponto de vista na seleção 
de conteúdos sobre os destinos a propor ao turista. Este tipo de obra é redigido, com frequência, na $3 .^{a}$ pessoa do singular, uma vez que o autor pretende focalizar a sua atenção sobre o espaço ou espaços a recomendar. Outras vezes, há um apagamento da autoria do guia, para que a obra surja como uma proposta duma instituição turística nacional ${ }^{3}$ ou regional ${ }^{4}$, tendo neste caso também um ponto de vista específico e o mesmo objetivo: atrair turistas.

O modelo dos guias atuais surgiu no século XIX e "foi transformado num padrão vulgarizado entre editoras e apreendido pelos viajantes, ou potenciais viajantes, que reconheceram a utilidade destes livros-guia na preparação ou no apoio a viagens" (Martins, 2011).

Quanto aos conteúdos, os guias turísticos apresentam, habitualmente, textos informativos sobre a história, a geografia, a natureza, a arte, a hotelaria, a restauração, os transportes, as vias de comunicação, enfim, um sem-número de assuntos úteis ao possível viajante dos destinos turísticos a oferecer/ vender. Do ponto de vista discursivo (Camlong, 1984), os enunciadores/autores constroem discursos performativos, procurando influenciar os leitores/turistas que os leem a cumprirem determinadas ações, ou seja, a irem conhecer/visitar os destinos turísticos apresentados.

Concordamos com a asserção de Maria João Cordeiro: "O guia turístico na sua materialidade compacta fornece já uma visão digerida e concisa da realidade exterior. Com efeito, no seu processo de 'arrumação' de países, regiões, culturas, povos e línguas, os guias descomplexificam-nos, traduzem-nos em modelos culturais, familiares e articulam-se com paradigmas de conhecimento e de criação de significado que deverão ser familiares aos seus receptores" (Cordeiro, 2017). As propostas disponibilizadas nos guias estão "traduzidas" para os "modelos culturais" conhecidos e familiares aos leitores desses guias, para que estes possam assimilar facilmente as informações transmitidas.

Em termos semióticos, os roteiros turísticos são textos mistos ou híbridos, compostos por mensagens textuais e visuais (Joly, 2009).

Nos guias mais antigos do nosso corpus, as mensagens visuais são fornecidas pelas capas desenhadas a cores por ilustradores da época (Bernardo Marques, Manuela) e por fotografias estáticas, a preto e branco. Atente-se em alguns exemplos abaixo (Foto 1; Foto 2).

Figura 1: Imagem da contracapa assinada pelo artista plástico Bernardo Marques.

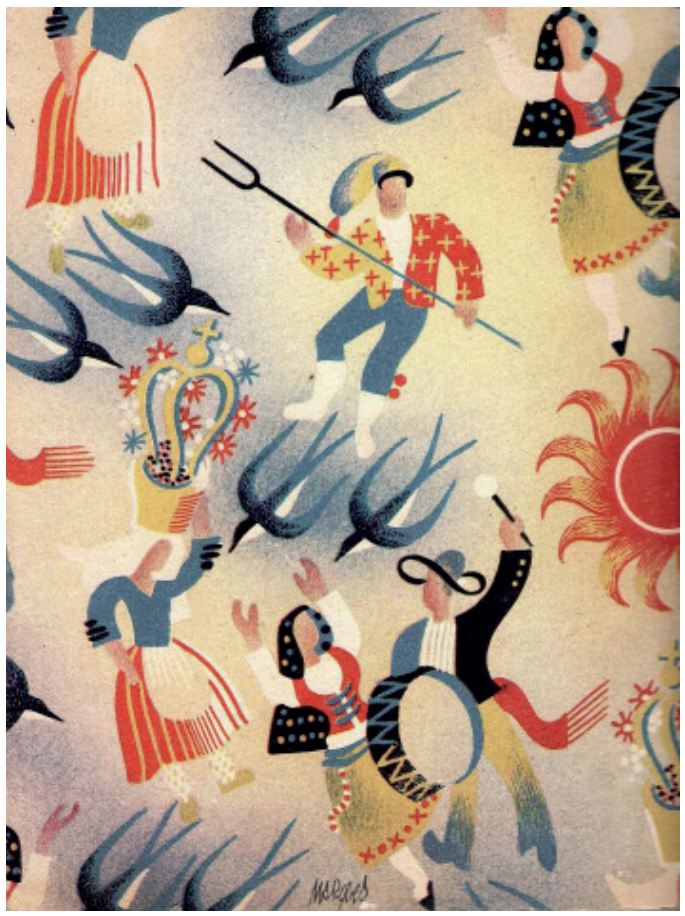

Guia (S.n. s.d. ) 
Figura 2: Imagem estática (S. João Pesqueira).

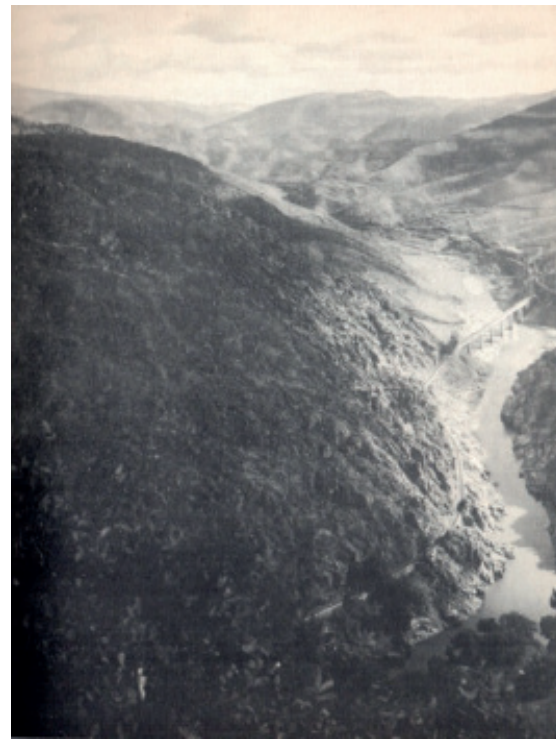

Fotógrafo anónimo. Guia (S.n. s.d. )

Nos mais recentes, aparece a cor, quer em fotografias quer em reproduções de desenhos, de pinturas, de cartazes, de rótulos, de gravuras (Foto 3).

Figura 3: Imagem de paisagens do Douro.

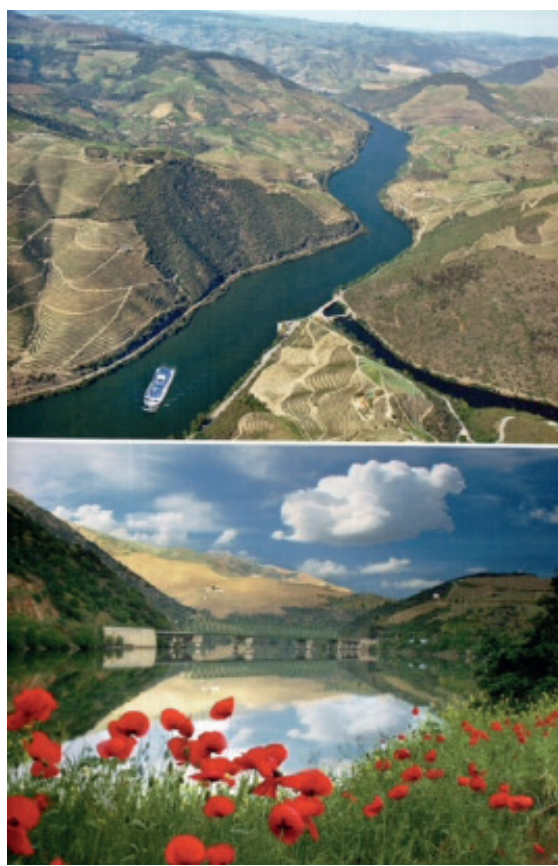

Créditos fotográficos de Rui Pires.

Guia (Veloso, Fonseca \& Fonseca, 2010) 
O género discursivo (Bakhtin 1984: 285) em estudo molda a construção dos destinos turísticos de acordo com as ideologias disponíveis nos diferentes períodos históricos ou como afirma Maria João Cordeiro: "Na verdade, os guias fabricam destinos, adotam pontos de vista, eliminam outros, hierarquizam atrações, destacam detalhes, descartam aspetos negativos, recomendam não só o que ver, mas também e sobretudo como ver, pensar, julgar e sentir" (Cordeiro, 2017), ou seja, condicionam as formas de ver e sentir dos turistas.

Como dissemos, os guias de viagens são discursos (Camlong, 1984) com uma forte componente performativa com o objetivo de criarem vontade aos turistas de visitarem os destinos propostos, seguindo as orientações impostas, quer pelos autores, quer pelos patrocinadores dos guias, isto é, os vários agentes do turismo: entidades centrais, regionais, editores, agentes económicos, enfim os "participantes diretos" do sistema turístico (Santana Talavera, 2015). As imagens dos destinos projetadas nos guias são "un conjunto de representaciones mentales del conocimiento o creencias sobre los atributos físicos del destino turístico en su conjunto (componente cognitivo) combinadas con las valoraciones y sentimientos que despierta (componente afectivo) (Baloglu, S. y Brinberg, D. 1997, citado por Santana Talavera, 2015 , p. 39). No fundo, as imagens projetadas nos discursos dos guias são compostas pela componente cognitiva que assenta nos elementos materiais dos destinos e na componente afectiva produzida no "consumidor-turista" (Santana Talavera, 2015). Outros conceitos encontrados em (Santana Talavera, 2015) são "imagem para venda" e "imagem promocional", ambas com o objetivo de atrair visitantes na fase de pré-compra.

Nos pontos seguintes, veremos como, nos discursos (Camlong, 1984) e ilustrações (Joly, 2009) dos guias turísticos do corpus escolhido, estão representados os "atributos físicos" dos destinos turísticos de Portugal e do Douro, no Estado Novo ${ }^{5}$, no pós-25 de Abril de $1974^{6}$ e no pós-consagração do Alto Douro a Património Mundial pela UNESCO.

\section{Os guias turísticos no Estado Novo}

No Estado Novo, as entidades políticas que coordenaram o turismo de 1933 a 1968, foram o Secretariado da Propaganda Nacional (SPN) e o Secretariado Nacional da Informação, Cultura Popular e Turismo (SNI), este último foi uma reformulação do primeiro, a partir de 1944. O SNI passou a estar dependente da Presidência do Conselho, concentrando as funções do órgão que exercia a censura e ainda as competências do Secretariado da Propaganda Nacional e dos Serviços de Turismo (Barros, 2016, p. 55). Por conseguinte, a fiscalização às publicações do domínio turístico passou a ter uma legislação muito apertada ${ }^{7}$, porque o órgão citado geria a imagem a transmitir e a promover do país dentro e fora de muros, com vista à projeção duma imagem do país com objetivos político-identitários e propagandísticos.

Para além dos conteúdos dos guias serem escrutinados, sobretudo, a partir de 1944, a autoria ${ }^{8}$ era deliberadamente retirada aos escreventes das obras, bem como a sua subjetividade, com o objetivo destas serem tão-só identificadas pelos editores SPN e SNI, os veículos da propaganda do regime.

António Ferro ${ }^{9}$ foi, inclusive, o autor moral e mandante da redação de muitos guias, impondo o seu estilo pessoal nos prefácios das obras, tal como está gravado, a título de exemplo, na obra, por nós analisada, de 1950: "Cartilha da Terra Portuguesa”, obra anónima, editada pelo SNI. No seu texto, Ferro exulta a "beleza" do país, usando termos religiosos "para os devotos da nossa Pátria, o catecismo da sua Beleza..." (S.n., 1950, p. 7), tão caros ao discurso formatado pelo regime e sintetizado no lema salazarista de "Deus, Pátria e Família".

Nos guias analisados, editados nas décadas de 40, 50, verificámos que os discursos veiculados são construídos com descrições hiperbólicas, ultraelogiosas dos espaços a visitar, notando-se um destaque exacerbado para o espaço da capital do país ${ }^{10}$. O discurso hiperbólico transmitido recria um cenário perfeito completado pelas fotografias estáticas a preto e branco dos monumentos mais conhecidos de Lisboa: "O Terreiro do Paço é o átrio de Lisboa. A quem o avista do rio dá logo a impressão da nobreza da cidade, e categoriza logo como capital a póvoa ribeirinha que escolheu para vir engrandecer-se, pelos séculos fora, ao contacto da sugestão, este poiso privilegiado" (S.n., 1953).

Secundariamente, a cidade do Porto é descrita no mesmo estilo exageradamente laudatório e assente nos estereótipos da heroicidade e do trabalho atribuídos historicamente ao povo portuense: "A cidade do Porto, vista de Gaia, oferece um espectáculo panorâmico de surpresa e grandiosidade. Sente-se através dos efeitos da policromia e do relevo do casario apinhado, uma trepidação da vida intensa do burgo heroico e operoso" (S.n., 1953). 
As demais cidades e vilas das "províncias continentais e ultramarinas" são expostas no mesmo estilo enfático e propagandístico emitido pelo poder do "império" português.

A imagem construída do Douro, nos roteiros turísticos nacionais deste período, era praticamente inexistente, surgia associada, a jusante, à imagem "promovida" (Santana Talavera, 2015) da cidade do Porto e de Gaia, destinos privilegiados do transporte e comércio do vinho do Porto, a montante, ligada à então "vila" do Peso da Régua "empório" do comércio do vinho generoso e cerne da "região demarcada do Douro". Administrativamente o Douro foi, durante séculos, um apêndice do Douro Litoral (Porto e Gaia) ou de Trás-os-Montes (Peso da Régua, Vila Real). A sua situação geográfica encravada entre duas províncias teve reflexos na imagem construída como destino turístico no Estado Novo. A divisão administrativa por províncias destacava apenas as capitais de distrito, não contemplando os demais territórios. Daí decorre, em parte, a débil da representação do Douro vinhateiro nos discursos em causa.

A nível visual, a imagem construída do Douro era, tão-somente, sugerida em diminutas e estáticas fotografias a preto e branco referentes, por exemplo, ao descarregamento de pipas de vinho do Porto nas margens do rio Douro ${ }^{11}$ em Gaia, de "barcos rabelos" no Douro ${ }^{12}$ e de homens carregando cestos vindimos ${ }^{13}$. O Douro era representado unicamente como o espaço vinhateiro produtor de vinho do Porto (Foto 4).

Figura 4: Imagem de homens descarregando pipas de vinho do Porto.

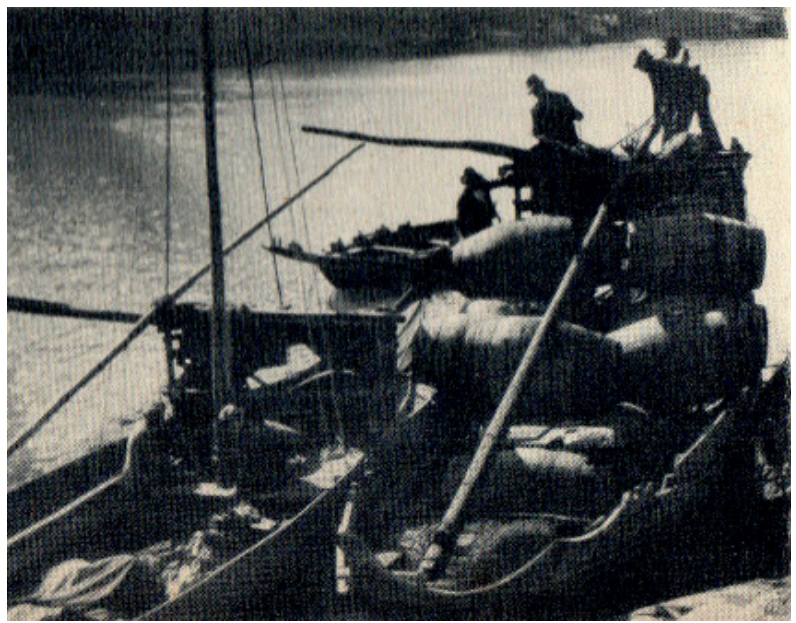

Fotógrafo anónimo. Guia (S.n., s.d)

O grande destaque promocional, ou seja, a imagem "construída para venda" (Santana Talavera, 2015, p. 42) do território duriense, salientava, sobretudo, a proeminência da cidade do Porto, que, aliás, nomeia o vinho generoso, subalternizando a imagem construída sobre a paisagem duriense produtora do vinho. Nos guias de viagem redigidos no Estado Novo, a principal imagem a encenar era a dum país "perfeito", dum espaço diversificado de paisagens litorais e interiores, continentais e ultramarinas, carregado de marcas históricas materializadas nos seus monumentos e na sua diversidade cultural.

Na década de 60, em 1968, foi extinto o SNI, tendo sido criada a Secretaria de Estado de Informação e Turismo, com uma Direção-Geral de Turismo, que teve como principal finalidade promover o turismo nacional no estrangeiro (Barros, 2016, p. 55).

Dos guias editados, nas décadas de 60 e 70, destacamos duas obras $\left(\mathrm{Cabral}^{14}\right.$; Pinto $\left.{ }^{15}\right)$ publicadas por uma editora do Porto (Avis). Os discursos produzidos, nestes dois guias, apresentam pontos de vista espaciais diferentes dos guias redigidos nas décadas anteriores. Evidenciam uma visão construída a partir do Norte, nomeadamente do Porto, bem diferente da projeção macrocéfala e centralista fabricada a partir da capital. Oliveira Cabral coloca a tónica nos espaços nortenhos, começando a sua abordagem por Viana do Castelo.

Nas duas obras, o Douro continua a ser representado como um espaço administrativamente inexistente, as referências a este território são similares às das obras das décadas anteriores, é mencionada novamente a ligação ao Porto e ao Peso da Régua, com uma alusão, nesta última, à criação da "Companhia Geral 
da Agricultura e Comércio dos Vinhos do Alto-Douro" e ao comércio do vinho do Porto realizado na Régua (Cabral, s.d., p. 115). O mesmo se verifica no Guia de Arnaldo Pinto, onde se regista que "Régua é o grande empório do precioso vinho do Porto" (Pinto, 1961, p. 363).

Estas duas obras alteram, na sua estruturação, o foco geográfico (do sul para o norte), porém nos conteúdos são devedoras das congéneres editadas nos decénios anteriores.

Nos finais da década de 60 e, no decurso da década de 70, surgiram guias diferentes dos habituais organizados e redigidos, em grande parte, por Sant'Anna Dionísio, o autor chamado a coordenar a coleção de Guia de Portugal da Fundação Gulbenkian, após o passamento de Raul Proença. Neste caso concreto, trata-se dum guia nacional subdividido em vários guias regionais, seguidores da divisão administrativa epocal, levada a cabo por um dos colaboradores do Guia: o geógrafo Amorim Girão.

O Guia de Portugal de Dionísio é uma obra de grande envergadura científica de pendor geográfico, edafológico, climático, paisagístico, histórico, arquitetónico e até linguístico ${ }^{16}$. No aspeto visual, conta com muita fotografia a preto e branco, mapas e inclusive esquissos do autor (Foto 5).

\section{Figura 5: Imagem de esquisso de Sant'Anna Dionísio “Alto Douro - O rio a montante da Quinta do Vesúvio" (Dionísio, 1995a).}

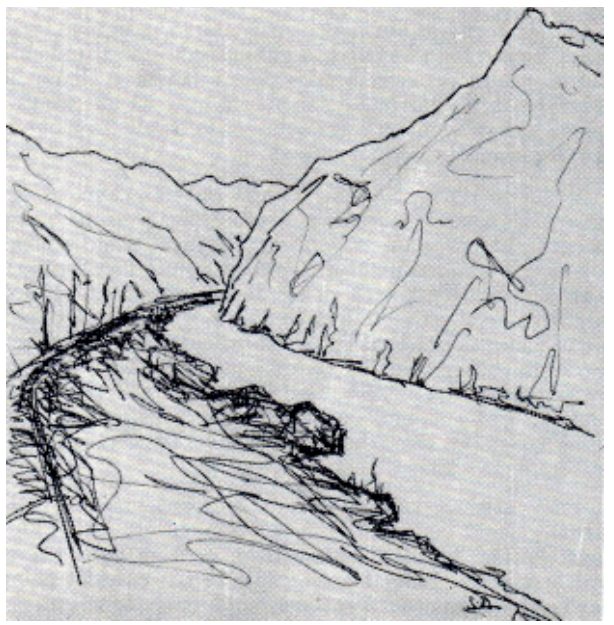

Tal como afirma Dionísio, no prefácio do I Tomo de Trás-os-Montes e Alto Douro, o ponto de vista apresentado é "novo". Atente-se, a propósito, na definição de guia do autor: "Um Guia é, por definição, uma obra de compromisso em que se conjugam, à medida que vão sendo precisas, indicações ou sugestões de ordem geográfica ou arqueológica, aqui e além associadas a outras que poderão ser discretamente reflexivas e até, por vezes, moderadamente inefáveis" (Dionísio 1995a, p. XXV). Não se trata dum simples guia, mas dum autêntico diário de viagens, contendo descrições detalhadas dos espaços a visitar, mas também reflexões sobre a paisagem, o homem duriense, a singularidade do destino.

O Guia de Portugal - Trás-os-Montes e Alto Douro foi desdobrado em dois tomos pela "grandeza de Trás-os-Montes, de mãos dadas com a gigantesca envergadura do Alto Douro" (Dionísio, 1995a, p. XXVIII). No nosso estudo, consideramos apenas estes dois volumes ${ }^{17}$.

Estamos perante o primeiro Guia de Portugal a ter em conta a grandeza e a dignidade da paisagem duriense. Nesta obra, o Douro não é um pequeno território acavalado entre Trás-os-Montes e o Douro Litoral com uma forte ligação ao Porto e a Gaia, através do rio Douro, como era considerado nos guias redigidos nas décadas anteriores e inclusive seguintes, mas, ao invés, é um território singular e desconhecido do grande público português.

$\mathrm{Na}$ introdução, o autor ressalta, desde logo, o "cunho telúrico e humano" e a "singularidade" paisagística da região de Trás-os-Montes e Alto Douro: "Para o apreciador de paisagens, será um segundo eldorado. Os anfiteatros do Douro, por si só, valem por todos os castelos do Loire e do Reno juntos". Convida o leitor/turista a fazer uma "pausada" viagem por este "recanto de Portugal" (Dionísio, 1995a, p. 2). No 
seu discurso, faz uso da performatividade da língua, com a finalidade de persuadir o viandante a fazer uma viagem a "este reino maravilhoso", para usarmos a expressão torguiana, e a descobrir panoramas únicos: "Que ele prossiga e procure, como deve, e verá cenários que nunca sonhou". Estamos perante a construção da imagem do "lugar mítico".

O desconhecimento incompreensível do leitor/turista português do espaço duriense ressalta no discurso dionisino: "Na pátria de Goethe ou de Byron, estas penedias já estariam humanizadas por alguma grande página de viagem, ou alguma visão onírica, à Macbeth. Entre nós, bem se poderá dizer que este formidando vale de Paraíso (cheio de portas do Inferno) é apenas conhecido dos timoneiros dos barcos rabelos que, desde há séculos, andam para cima e para baixo, ora cautos, ora pasmados, em silêncio análogo aos seus antepassados das remotas citânias e dos remotíssimos 'castros"' (Dionísio, 1995a, p. 525).

Do ponto de vista discursivo, há mudanças significativas, na escrita dos restantes guias publicados durante o Estado Novo, e, na dos guias de Sant’Anna Dionísio. Nos primeiros, há um apagamento do autor e da sua subjetividade, tornando-se os lugares de visitação os focos do discurso: Lisboa, Porto, Coimbra, aparecem como os protagonistas dos relatos pejados de referências históricas grandíloquas materializadas nos monumentos, nos museus e nas tradições populares. A construção discursiva dos guias desse período baseia-se numa seleção clara pela encenação da "grandeza" das duas principais cidades e restantes capitais de distrito, eliminando os pequenos espaços, tal como o Douro vinhateiro.

Nos guias de Santana Dionísio, há uma neutralização da sua subjetividade no discurso usando a $3{ }^{\text {a }}$ pessoa do singular, todavia a utilização duma linguagem imagética, poética, sugestiva, "substantiva", para usar um termo dionisino, incita o leitor/turista à descoberta dum "paraíso" insondado, à procura do "lugar mítico", tão caro ao "novo romantismo" recriado turisticamente na contemporaneidade.

À exceção das obras dionisinas, as imagens "construídas para venda" e "promocionais" (Santana Talavera, 2015, p. 40) dos destinos turísticos eram fortemente controladas, nos guias redigidos no Estado Novo, pois o poder político mediava a construção dos olhares turísticos sobre os destinos a vender.

\section{Os guias turísticos após Abril de 74: representações do Douro}

As estratégias políticas para o setor turístico no pós-25 de Abril mudaram. Com a chegada da democracia, deram-se alterações políticas e legislativas significativas na área do turismo. Em setembro de 1974, é criada a Subsecretaria de Estado do Turismo e a Direção-Geral de Turismo. Em 1979, cria-se a Secretaria de Estado do Comércio Externo e Turismo (Barros, 2016, p. 57).

A referida Secretaria de Estado, nos anos 80 e 90, passa a ter assento no Conselho de Ministros, sendo tutelada pelo Ministério do Comércio e Turismo. A partir de 1995, depende do Ministério da Economia (Barros, 2016, p. 57) e, sobretudo, ganha importância político-económica.

No período em causa, continuaram a ser editados guias turísticos nacionais, porém apareceram igualmente guias de extensão regional, assentes nas divisões das regiões turísticas dependentes da Direção-Geral de Turismo, tendo como objetivo a promoção do turismo nesses espaços.

Para este lapso temporal, examinámos três guias, dois de âmbito nacional (Ribas, 1984; Oliveira, 1990) e um de âmbito regional (S.n., 1982).

O primeiro autor selecionou como unidade de trabalho a "região / província", herdeira da antiga divisão administrativa de Amorim Girão (Ribas, 1984, p. 5), já alterada na data da publicação da obra. Versou temas de história, meio físico e humano, património cultural, etnológico e folclórico, música, danças, teatro tradicional, usos e costumes populares, artesanato, gastronomia e culinária (doçaria e vinhos), festas e romarias, termalismo, miradouros, monumentos, museus, hotelaria e afins (Ribas, 1984, p. 18-27) nas diferentes regiões.

O Alto Douro integra, nesta obra, a região de Trás-os-Montes. O olhar sobre o Douro não mudou, surge associado aos habituais estereótipos: "os socalcos dos vinhedos em anfiteatro" e as "tradicionais quintas durienses". O Pinhão é representado como sendo o "centro produtor vinícola da região duriense", assim como a "Régua é o seu centro comercial". É repetida igualmente a ancestral ligação da região duriense ao Porto e a Gaia pelos "belos barcos rabelos" (Ribas, 1984, p. 21). O Douro continua a não ser promovido como destino turístico, mas tão-só como espaço produtor de vinho generoso.

O segundo escolheu uma divisão ainda mais parcelar em concelhos. O Douro, não pertencendo a um único concelho, não aparece autonomamente, muito menos com uma imagem diferenciadora. Ocorre em dispersas alusões no brevete do Peso da Régua, que abarca também os lugares durienses: Alijó, Mesão Frio, Pinhão, Sabrosa e Santa Marta de Penaguião. As indicações fornecidas são, apenas, constituídas por informes históricos, geográficos (clima, hidrografia), toponímicos, culturais (Oliveira, 1990, p. 215). 
Surge ainda uma alusão ao termalismo nas Caldas de Moledo e a indicação de quintas "dignas de visita": "Monsul, Santo António, Mourão, Laranjeiras e Costa" (Oliveira, 1990, p. 215). São apontadas outras quintas em Mesão Frio "Quinta de Santiago", no Pinhão "Quinta das Carvalhas" com vistas panorâmicas sobre o "país do vinho" (Oliveira, 1990, p. 216-17), apontando para o surgimento do enoturismo.

No discurso dos dois guias, tal como nas obras publicadas nas décadas anteriores, a "imagem construída para venda do Douro" (Santana Talavera, 2015) continua a ser apenas a do "país do vinho", dos socalcos de vinhedos produtores do "afamado" vinho do Porto.

O terceiro guia abordado é de âmbito regional: "Guia Turístico: Marão - Douro e Trás-os-Montes" (S.n., 1982). A divisão administrativa escolhida foi a das regiões de turismo ${ }^{18}$. À época, na Região de Turismo da Serra do Marão, estavam incluídos alguns concelhos durienses (Alijó, Mesão Frio, Sabrosa, Santa Marta de Penaguião e Vila Real) e concelhos de vários outros distritos (Amarante, Baião, Cabeceiras de Basto, Celorico de Basto, Mondim de Basto, Ribeira de Pena). A Região de Turismo do Douro Sul contemplava também alguns concelhos durienses (Armamar, Lamego, Tabuaço, S. João da Pesqueira). O concelho do Peso da Régua estava incluído na Junta de Turismo de Caldas de Moledo e o concelho da Meda encontrava-se isolado (S.n., 1982, p. 3). Mais uma vez, a divisão administrativa e turística proposta pelas Regiões de Turismo não fornecia uma imagem espacial una e coerente do Douro, ao invés, disseminava as informações sobre este destino, tal como os guias nacionais anteriores, dificultando ao turista a organização duma viagem ao território duriense. Os informes transmitidos eram semelhantes aos demais guias: "localização e clima; introdução histórica; aspectos paisagísticos, aspectos socioculturais, gastronomia, entretenimento, informações úteis".

A componente gráfica dos três guias é composta por fotografias a cores em formato tradicional dos lugares, dos monumentos, da paisagem (vinhedos, vindimas), das pessoas e também por alguns mapas (Joly, 2009).

No fundo, nos discursos dos guias turísticos, elaborados após o 25 de Abril e 1974, a área geográfica considerada no Douro continuara a estar disseminada pelos lugares ou concelhos do eixo urbano - Vila Real - Régua - Lamego, espaço, aliás, já contemplado nos decénios anteriores.

Nas décadas de 80, 90, a representação minimalista do destino Douro nos guias analisados comprovou que este destino turístico era ignorado tanto pelo turismo nacional como regional.

\section{A consagração do Douro a património mundial: ecos nos discursos dos guias turísticos}

Como constatámos, o Alto Douro Vinhateiro, a mais antiga região vitícola regulamentada do mundo, foi um território pouco divulgado e promovido em termos turísticos pelo poder central e regional até ao final do século XX.

Importa notar que a candidatura do Alto Douro Vinhateiro, um terroir construído pelo homem e produtor do "vinho do Porto", foi encabeçada e colaborativa das entidades regionais e locais situadas no norte de Portugal e na bacia do Douro (Fundação Rei Afonso Henriques, Comissão de Coordenação e Desenvolvimento Regional do Norte, Universidade de Trás-os-Montes e Alto Douro e autarquias da região), não foi uma candidatura proposta pelo poder central. A atribuição da chancela da UNESCO, a 14 de dezembro de 2001, na categoria de "Paisagem Cultural Evolutiva e Viva"19 veio colocar os holofotes sobre um destino turístico até aí conhecido tão-somente pelo enoturismo.

A consagração mundial do Alto Douro Vinhateiro trouxe obrigações ao poder central. Todavia, só em 2006, no âmbito das comemorações dos 250 anos da $1{ }^{a}{ }^{2}$ região vitícola demarcada e regulamentada do mundo, foi lançada a semente da Estrutura de Missão para a Região Demarcada do Douro ${ }^{20}$, um estrutura dependente do Ministério do Ambiente, do Ordenamento do Território e do Desenvolvimento Regional criada com o objetivo de "dinamizar acções para o desenvolvimento integrado da Região do Douro e promover a articulação entre as entidades da administração central e local com competências na região, bem como articular a participação e a iniciativa da sociedade civil”"21. A Missão tornou possível uma articulação colaborativa com todos os agentes na região, desde as autarquias locais, aos empresários e às universidades. De 2006 a 2014²2, o destino turístico do Alto Douro Vinhateiro foi promovido nacional e internacionalmente. Com as estratégias de governação aplicadas ao território duriense, a partir da criação da Estrutura de Missão para o Douro, em 2006, e do Polo de Desenvolvimento Turístico do Douro, em 2008, passou-se a juntar à "componente cognitiva" da imagem construída do Douro a "componente afetiva" (Santana Talavera, 2015). Os discursos dos guias turísticos editados com o apoio destas duas entidades construíram imagens que apelaram tanto aos "atributos físicos" do destino como à "perceção" do "consumidor-turista" (Santana Talavera, 2015). Como veremos adiante. 
O destino Douro foi considerado um dos centro ${ }^{23}$ nevrálgicos do turismo nacional e mereceu especial atenção do poder central. O Polo de Turismo do Douro ficou sediado, no território, em Vila Real e esteve em funções até 2015. Foram inúmeras as atividades promotoras fomentadas por este organismo, entre elas, a publicações de guias ${ }^{24}$ para divulgação do destino turístico Douro.

A consagração do Alto Douro Vinhateiro a Património Mundial, a atuação dos diferentes "atores do sistema turísticos" (Santana Talavera, 2015), com destaque para alguns setores da área turística ${ }^{25}$ e as consequentes decisões político-estratégicas do poder central, com a criação das entidades acima citadas, de 2006 a 2015, gizaram, nesse período, uma "imagem construída para venda" e "uma imagem promocional" (Santana Talavera, 2015) do destino Douro. Porém essas imagens do destino sofreram um forte revés, a partir de 2015, com a perda de poder de decisão da Estrutura de Missão para o Douro e com a extinção do Polo de Turismo do Douro e a consequente integração dos concelhos do Douro na macro Entidade Regional de Turismo do Porto e Norte de Portugal (ER-TPNP), coincidente com a NUTS II: Norte de Portugal.

Para verificarmos a emersão da "imagem construída para venda" e da "imagem promocional" do destino Douro nos discursos dos guias analisados, considerámos dois subgrupos publicados após a referida consagração da UNESCO.

\subsection{Omissão da imagem do destino Douro}

No primeiro subgrupo, constituído por dois guias, a unidade geográfico-territorial eleita foi a da citada Entidade Regional de Turismo do Porto e Norte ${ }^{26}$.

No segundo, composto por seis, incluímos um guia que selecionou como unidade espacial os três pontos fulcrais do percurso do rio Douro: Porto, Gaia e Douro ${ }^{27}$ e os restantes cinco que destacaram o território do Douro ${ }^{28}$.

No primeiro subgrupo, incluímos dois guias: um, escrito por uma autora italiana e traduzido em português (Savelli, et al., 2002), e um segundo publicado em 2012 pela Deco Proteste. Ambos consideraram como unidade de trabalho o extenso espaço geográfico do Porto e Norte de Portugal associado à ER-TPNP. Estes dois textos subalternizaram ou omitiram a imagem do Alto Douro Vinhateiro. Atente-se nos exemplos concretos: Savelli usou no seu discurso os habituais, desgastados e desatualizados estereótipos sobre o Norte e os nortenhos, gente laboriosa de "origens camponesas", ligados às "tradições", "folclore" e à religiosidade (Savelli, et al., 2002, p. 3-4). Iniciou o seu percurso por uma breve sinopse da origem de Portugal, abrindo o guia com a descrição da cidade do Porto pejada de chavões regionais: "cidade trabalhadora, empreendedora, dura, comercial, industrial, moderna" contraposta à "rival" cidade de Lisboa "cidade rica, bonita e cheia de fascínio" (Savelli, et al., 2002, p. 7). Os conteúdos abordados são, sobretudo, a história, a arte, a gastronomia, os vinhos com a indicação degastada do "célebre Porto" (Savelli, et al., 2002, p. 4). A Régua é mais uma vez considerada, como nos discursos dos guias das décadas passadas, um entreposto do vinho do Porto "vive do vinho e para o vinho, e que já no século XVIII era a base de onde partiam os Rabelos" (Savelli, et al., 2002).

A composição gráfica é constituída por fotografias a cores em tamanho agrandado. A representação imagética do Douro ocorre em esparsas fotografias a cores dos tradicionais barcos rabelos, dos azulejos das antigas estações de comboio, dos vinhedos, das quintas.

Tal como nos discursos dos guias das décadas anteriores, o destino Douro não aparece autonomizado nesta obra. A imagem do Douro surge associada apenas aos seus "atributos físicos" à história e à fama do vinho do Porto, ou seja, há um decalque da visão tradicionalista do "País Vinhateiro", seguidora da imagem construída nos séculos anteriores.

O segundo guia, bem mais recente, publicado, em 2012, pela Deco Proteste (Mendes, et al., 2012), centra-se no mesmo espaço alargado (Porto e Norte), ou seja, na atual divisão turística em entidades regionais. A sua estrutura assenta num conjunto de 11 "percursos de evasão", isto é, de 11 propostas de itinerários concretos a alguns territórios do Norte de Portugal, não incluindo, contudo, um único percurso para o Alto Douro, Património da Humanidade, tão-só para: 1 Viana do Castelo, 2 Arcos de Valdevez, 3 Vieira do Minho, 4 Chaves, 5 Bragança, 6 Braga, 7 Mirandela, 8 Miranda do Douro, 9 Porto, 10 Vila Real e 11 Vila Nova de Foz Côa. Nestas condições, a representação do Douro não existe, ocorrem somente algumas passagens e fotografias a cores no verbete referente ao Pocinho, com uma alusão a "locais de grande beleza" (Mendes, et al. 2012, p. 140). No item relativo a Vila Nova de Foz Côa, há uma pequena referência aos miradouros do Vale do Douro: "com encostas escadeadas em socalcos ornamentados de vinhas" (Mendes, et al., 2012, p. 147).

A representação do destino Douro, neste guia, é inexistente. O potencial turista do norte de Portugal não encontrará informação sobre um Património Mundial da Unesco que territorialmente está localizado 
no norte do país e deveria ser promovido pela ER-TPNP. Contudo como esta entidade atualmente agrega 86 municípios e 4 patrimónios mundiais da Humanidade (Centro Histórico do Porto, Centro Histórico de Guimarães, Vale do Côa e Alto Douro Vinhateiro), não os promove a todos com o mesmo destaque.

\subsection{Imagem do destino Douro nos guias mais recentes}

No segundo subgrupo de guias, incluímos o guia (2009): The Best Guide Portugal: Porto Gaia \& Douro, uma edição bilingue em português-inglês e os restantes cinco (Moreira, 2008; S.n., 2010; Veloso, Fonseca \& Fonseca, 2010; Tapada, 2012; Tapada, 2013).

Os responsáveis desta primeira obra selecionaram o triângulo geográfico-histórico, económico e turístico constituído pelo Porto, Gaia e Douro, graças à transversalidade do rio Douro. Utilizaram duas línguas para abarcarem vários tipos de público: nacional e internacional. Quanto à sua estrutura formal, o guia está dividido em três secções: a primeira é uma "aproximação histórica e cultural" ao Porto. A segunda trata a cidade de Gaia, com a indicação dos locais a visitar no concelho, salientando a zona Ribeirinha, o seu cais com as caves do Vinho do Porto. A terceira seç̧ão é consagrada ao Douro. Foram destacados os vários tipos de turismo a praticar: o turismo fluvial, o cultural, o ferroviário e o enoturismo (Castanheira, 2009, p. 3).

No que respeita aos conteúdos abordados fornece informes de vários domínios (histórico, cultural, económico, turístico) em pequenos verbetes constituídos por duas colunas: uma, com o texto em inglês, e, outra, em português. Este guia é um verdadeiro roteiro para o turista nacional e internacional. Todos os locais aconselhados a visitar estão devidamente referenciados. Consulte-se, a título de exemplo, o verbete sobre a Torre dos Clérigos (Castanheira, 2009, p. 43).

O discurso deste guia é lexicalmente mais atualizado, não recorre aos estereótipos do passado. A título de exemplo, atente-se na descrição da cidade do Porto: "O Porto é, por excelência, uma cidade de contrastes. Quem chegue de comboio e atravesse a ponte de S. João a caminho de Campanhã terá o vislumbre de uma cidade em anfiteatro, dominada pelos tons escuros do granito e com uma silhueta marcada por referências que mudaram em muitas décadas, do arco metálico da Ponte Maria Pia ao imponente volume da Sé, do bairro medieval da Ribeira às torres das igrejas dos Clérigos ou da Lapa" (Castanheira, 2009, p. 22).

Na cidade de Gaia, o realce centra-se nas "melhores vistas sobre o Douro e a Ribeira do Porto", o cais de Gaia, as caves do Vinho do Porto, a serra do Pilar, o Museu Teixeira Lopes, o Parque Biológico de Gaia, o passeio marítimo pelas praias de bandeira azul, o Parque e Zoo Santo Inácio (Castanheira, 2009, p. 77-84).

A seç̧ão dedicada ao Douro enceta com uma sucinta resenha histórica da mais antiga região demarcada e regulamentada do mundo, passando pela consagração a Património Mundial da Humanidade acompanhados de conselhos para viagens ao Douro por vários meios de transporte: carro, comboio e barco. $\mathrm{O}$ convite à aventura é seguido dos pontos mais interessantes a visitar, por exemplo: Casa de Mateus, Favaios, Castelo de Ansiães, Senhora da Ribeira, Lamego, João da Pesqueira, Castelo de Penedono, Parque Arqueológico do Côa, São Salvador do Mundo (Castanheira, 2009, p. 86-96). É fornecida a lista dos principais hotéis da região (Castanheira, 2009, p. 114-125), restaurantes (Castanheira, 2009, p. 126-134), comércio (Castanheira, 2009, p. 135-144), vouchers e mapas.

A componente visual deste guia é constituída por inúmeras fotografias a cores, quer a ilustrar os textos em si quer nas páginas de publicidade. As fotografias da região do Douro estão graficamente atrativas (Castanheira, 2009, p. 86-89).

Este guia de todos os analisados até este momento é o único que constrói uma imagem "para venda" e "promocional" (Santana Talavera, 2015) do destino Douro equivalente às apresentadas para os destinos de Porto e Gaia.

O guia (2008) Douro: guia turístico: Douro singular, Douro universal de José Moreira, publicado um ano antes do anterior, centra-se especificamente no destino turístico do Douro. Nesta obra, o Douro é representado como um éden de sentidos, numa referência intertextual (Foucault, 1969) aos guias de Sant'Anna Dionísio $(1969,1977)$ redigidos algumas décadas atrás. Neste guia em particular, o autor criou um conceito inovador para reinterpretar a paisagem duriense, criou o conceito/neologismo "dourorama" (Moreira, 2008, p. 19-21), isto é, uma paisagem que desperta sentimentos apaziguadores e assombrosos, integrando as componentes "cognitiva" e "afectiva" do destino.

O discurso da citada obra ressalta a singularidade do destino Douro, desde logo, apontada no subtítulo: Douro singular, Douro Universal. Universal, por ser Património da Humanidade, obviamente. O Douro é promovido como um éden estimulador dos cinco sentidos do turista (visão, audição, olfato, 
tato, sabor), uma paisagem natural e cultural, um "dourorama", apelando a uma fruição "vagarosa" da paisagem nas várias estações do ano e nas várias sub-regiões durienses (Douro Superior, Cima Corgo, Baixo Corgo). Esta obra propõe ao visitante do Douro a prática dum turismo de experiência e emoção, de turismo cultural e da natureza ${ }^{29}$.

A nível visual, o guia oferece inúmeras fotografias a cores. As informações úteis, para se destacarem do discurso do guia propriamente dito, surgem em páginas impressas a diferentes cores, tornando a consulta mais facilitada. Os mapas ilustram os circuitos a fazer nas três sub-regiões do Douro (Foto 6).

Figura 6: "Escadório monumental de geios ou socalcos".

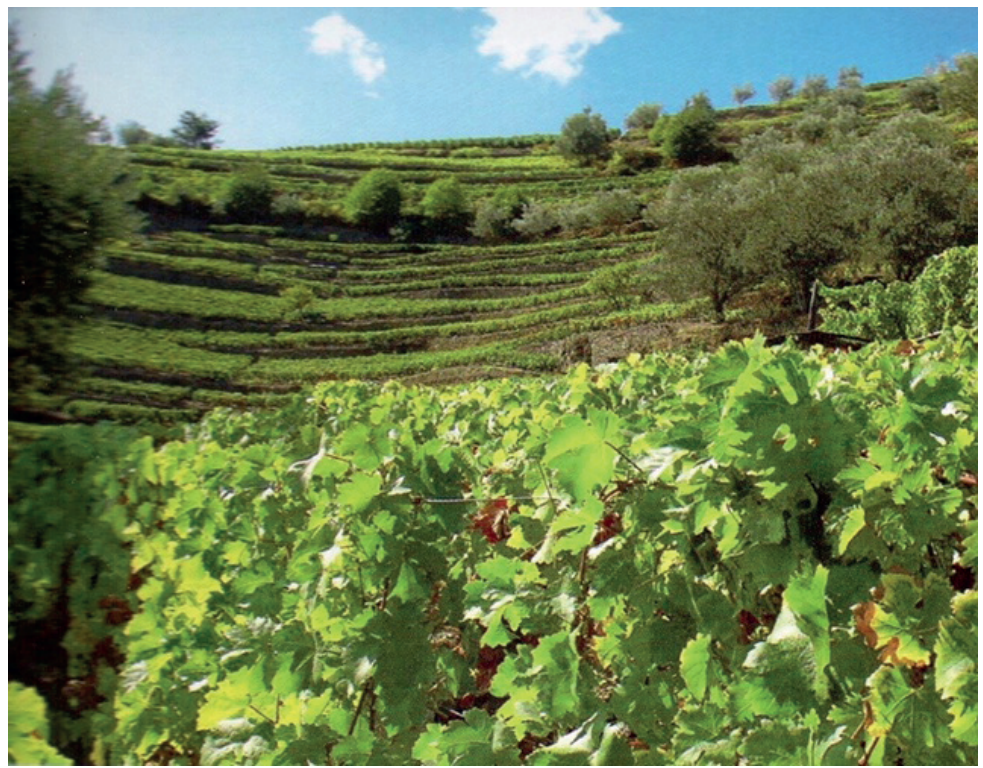

Créditos fotográficos: José Moreira (Moreira, 2008)

Um outro guia que obedece à construção do mesmo tipo de imagem "para venda" e "promocional" é o guia (2010): Douro: viagens e histórias. Esta obra inicia-se com um texto do historiador Gaspar Martins Pereira, retratando o Douro histórico e poético. Os seus autores escolheram começar por apresentar a cidade do Porto, tratando as designações pelo vinho do Porto, a história da Região Demarcada, a iconografia dos rótulos e cartazes do vinho do Porto, assuntos igualmente expostos no guia anterior (Moreira, 2008). Porém, este guia oferece uma parte original: a introdução duma componente ficcional, "baseada em factos reais", escorada na recriação de pequenas histórias epistolográficas à volta do amor humano e do amor ao chão duriense: "Abraço do Sol, Abraço que aperta a distância" (Veloso, Fonseca \& Fonseca, 2010, p. 20-21).

Este guia, tal como o de Moreira (2008), convida os leitores à prática dum turismo de experiência e emoção, do turismo cultural, do enoturismo nas três sub-regiões do Douro. Alarga o âmbito espacial propondo visitas às auréolas durienses, como subdestinos: as aldeias vinhateiras, o Parque do Douro Internacional e outros concelhos limítrofes.

A nível imagético, as fotografias a cores são expressivas e os textos ficcionais tornam o guia mais pessoalizado, mais íntimo, encerrando com um mapa das três sub-regiões do Douro.

Os dois guias citados têm versões em várias línguas, contam com várias edições, continuando a ter procura por parte do público nacional e internacional. Nas duas obras, encontramos uma "imagem construída para venda" e "uma imagem promocional" (Santana Talavera, 2015) do destino Douro.

Os três guias a seguir analisados resultaram duma estratégia colaborativa, criada entre a Estrutura de Missão para o Douro e o Polo de Desenvolvimento Turístico do Douro, na construção duma "imagem promocional" (Santana Talavera, 2015) específica do destino Douro. 
O guia (2012): Douro: guia turístico do Douro, editado pelo Polo de Turismo do Douro, sem autoria, retoma intertextualmente (Foucault, 1969) a metáfora paradisíaca dionisina, apelando aos "novos turismos", para além do enoturismo, ao turismo da natureza e turismo rural e cultural.

Os conteúdos abordados subdividem-se em temas históricos: "as origens", geográficos contemplando: "as geografias do Douro", onde se incluem (Região Demarcada do Douro, Beira Douro, Parque do Côa, o Rio e as Áreas Protegidas, o clima), a promoção dos produtos endógenos da região (os vinhos, o artesanato), do património cultural popular (as festas e romarias), bem como a apresentação de itinerários / rotas turísticas específicas para o espaço duriense alargado, incluindo visitas às aldeias vinhateiras, ao património edificado de todos os concelhos do Douro, aos museus Douro, do Côa, de Lamego; itinerários culturais concretos para a região duriense, por fim, a hotelaria, o alojamento e as informações gerais. A novidade deste guia consiste na apresentação de rotas específicas explicadas e acompanhadas dos mapas das estradas, pontos de interesse a visitar com georreferenciação, propondo um território bastante mais amplo e complementar do Alto Douro Vinhateiro.

Este guia utiliza, tal como os dois anteriores (Moreira, 2008; Veloso, Fonseca \& Fonseca, 2010), um discurso sugestivo, apelativo e poético escorado intertextualmente (Foucault, 1969) na metáfora do Douro paradisíaco, estimulador dos cinco sentidos e criador de experiências múltiplas e inesquecíveis nos turistas, quer a nível paisagístico, enófilo, gastronómico ou de lazer, aliando, tal como os anteriores, a "componente cognitiva" e "afetiva" na construção da imagem do destino.

No mesmo ano de 2012, é publicado pela mesma entidade o guia: Douro: Guia Turístico da Natureza: paisagem, geologia, fauna, flora, turismo com textos de Alberto Tapada. Depois da disponibilização dum guia turístico abrangente (S.n., 2012), a referida Entidade Regional resolveu criar um roteiro mais específico que mostrasse ao turista outras valências turísticas do mesmo destino, nomeadamente, apelando à prática do geoturismo, baseado nas "relevâncias geológicas, botânicas e de fauna, assim como o elevado valor dos seus parques naturais, miradouros, sabores ancestrais, corredores ecológicos, ecossistemas e, ainda, os lugares 'imperdíveis' que o Vale do Douro oferece"30 (Tapada, 2012, p. 2). O objetivo foi o de evidenciar as possibilidades da prática de "novos turismos" num destino turístico tradicionalmente associado ao enoturismo (Foto 7).

\section{Figura 7: Capa do Guia Douro: Guia Turístico da Natureza (Tapada, 2012)}

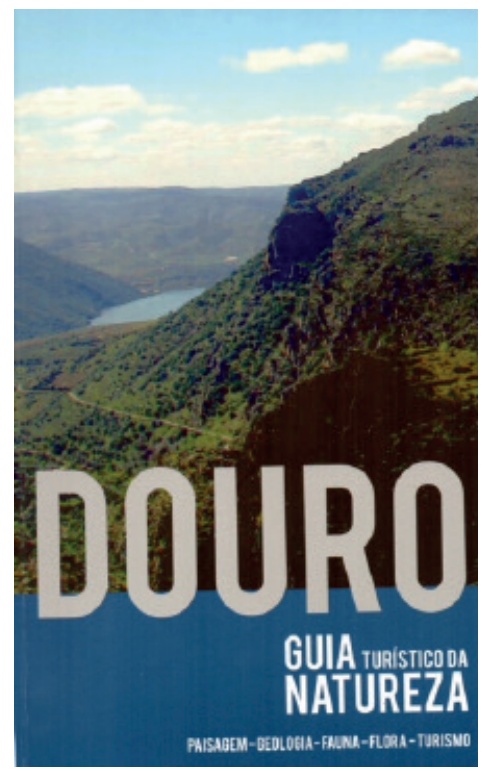

Créditos: Filipe Alves 
Esta obra apresenta-se como "uma ferramenta de usufruto de parte deste abundante território natural integrado no Polo Turístico do Douro". Propõe "várias tipologias de observação", os locais de observação com georreferenciação e exemplos das "espécies observáveis". Ressalta a caracterização do Douro do ponto de vista geológico, do rio Douro "construtor de paisagens" e da sua vegetação (Tapada, 2012, p. 7-15).

As propostas turísticas deste guia, tal como do anterior, estendem-se a um vasto território envolvente do Alto Douro Vinhateiro, pois a entidade regional centrou o seu objetivo na diversificação da oferta turística do destino, apontando para os "novos turismos" ou para uma "imagem construída para venda" e "promocional" (Santana Talavera, 2015). Este guia encontra-se disponível em formato digital (PDF).

No ano seguinte, o Polo de Turismo do Douro, a Estrutura de Missão para o Douro e a CCDR-N patrocinaram uma edição de grande divulgação: o Guia Turístico da Rede das Aldeias Vinhateiras do $D_{\text {Douro }}^{31}$, aldeias com um "vasto património construído e imaterial, uma memória coletiva", reforçando a necessidade da construção duma "imagem para venda" do destino Douro, com um leque de novas opções turísticas ou subdestinos. A rede das sete aldeias ancestrais, associadas à cultura da vinha e do vinho, circundantes do Alto Douro Vinhateiro, nasceu em 2001, com o objetivo de acrescentar "fatores distintivos" ao território, contribuindo para a "imagem construída para venda" (Santana Talavera, 2015) do destino.

O guia apresenta um enquadramento ambiental, geológico, histórico do Douro "o canhão da mediterraneidade" das aldeias vinhateiras (Tapada, 2013, p. 15), alusão intertextual (Foucault, 1969) às obras dionisinas, e um mapa da área geográfica abrangida pelo Polo Turístico do Douro, onde se incluem todas as aldeias. A abordagem histórico-cultural de cada aldeia inicia-se com uma grande imagem da mesma com um título caraterizador $^{32}$, um mapa, e os itinerários (local, tempos, km, estradas) para se chegar à mesma, bem como a narrativa da história do povoado, o património edificado, um circuito aconselhado, uma figura ilustre, sugestões de visitas nas proximidades (Tapada, 2013, p. 18-29). Esta obra apresenta ainda uma "Grande Rota das Aldeias Vinhateiras" encetada em Vila Real e terminada em Lamego ou Peso da Régua, propiciando ao visitante o contacto com uma paisagem duriense, o seu património construído, vernacular, apelando ao turismo cultural (Tapada, 2013, p. 85-97), apoiado no tradicional eixo Vila Real-Lamego-Peso da Régua.

Os guias turísticos centrados na promoção do destino Douro publicados, após o surgimento da Estrutura de Missão para o Douro, em 2006, e a criação da Entidade Regional de Desenvolvimento Turístico do Douro, em 2008, construíram uma "imagem para venda" e uma "promocional" diferenciadoras e potenciadoras do Douro, ultrapassando o âmbito do enoturismo, propondo tipos de turismo emergentes, como por exemplo: o geoturismo, o turismo de natureza, o turismo rural e cultural.

\section{Discussão e conclusões}

Analisámos numa perspetiva documental, discursiva e imagética um corpus de 22 guias turísticos, publicados, em suporte papel, num lapso temporal de cerca de 70 anos (1941 a 2013). Estes materiais enquadram-se num género discursivo específico, no qual os seus autores e/ou patrocinadores constroem e/ou impõem pontos de vista, subjetivos, sobre os destinos a promover para venda.

A pesquisa efetuada permite concluir que os roteiros publicados na segunda metade do século XX, estudados por nós, evidenciam discursos que representam "formas de ver a paisagem" (Sarmento, 2004) "tradicionais" recuperadas das narrativas do século XIX construídas sobre o "Paiz Vinhateiro", por exemplo, por J. J. Forrester.

Os guias redigidos e publicados até à data da consagração do Alto Douro Vinhateiro a Património Mundial da UNESCO, em 2001, nos seus discursos ainda veiculam representações "dum passado reconstruído" que narra a história da vinha e do vinho generoso ou "vinho do Porto", apontando, no essencial, tão-só para os "atributos" materiais do "País Vinhateiro", tais como: (Cabral, s.d.; Pinto, 1961; S.n., 1982; Ribas, 1984; Oliveira, 1990).

Outros mais recentes, nomeadamente (Savelli, et al., 2002; Mendes, et al., 2012), partem da atual divisão espacial da macro Entidade Regional de Turismo do Porto e Norte de Portugal (ER-TPNP) e nos seus discursos omitem ou minorizam o destino do Alto Douro Vinhateiro, pois não lhe conferem tratamentos discursivo e imagético compatíveis com o seu estatuto de Património Mundial da UNESCO, como mostrámos atrás. Precisaremos de, num momento posterior, alargar a nossa análise a um corpus de guias turísticos mais vasto patrocinado por esta entidade regional de turismo para confirmar esta suspeita.

Ademais importa salientar que a classificação do Alto Douro Vinhateiro a Património da Humanidade na categoria de "Paisagem Cultural Evolutiva e Viva" conduziu a uma mudança positiva das estratégias de governação para o território com a criação da Missão de Estrutura do Douro e do Polo de Turismo do 
Douro, tendo estes dois "participantes diretos" (Santana Talavera, 2015) do sistema turístico, numa ação colaborativa apoiado edições de guias turísticos, em suporte papel, que construíram discursos direcionados para a criação duma "imagem para venda" e duma "imagem promocional" (Santana Talavera, 2015) do destino Douro. Esses guias com enfoque no terroir patenteiam discursos escorados na "componente cognitiva" (tangível) e "afetiva" (intangível) do Alto Douro Vinhateiro, são eles: (Moreira, 2008; S.n., 2010; Veloso, Fonseca \& Fonseca 2010; Tapada, 2012; Tapada, 2013), entre outros.

Em síntese, os discursos dos guias turísticos analisados admitem afirmar que a "imagem para venda" e a "imagem promocional" do Douro, nos últimos anos, após a chancela UNESCO, é uma "imagem" holística e complexa evocadora das vertentes cognitiva e afetiva.

Poderemos, noutros momentos, com um alargamento da nossa análise a corpora de prospetos turísticos, de revistas e doutros materiais promocionais do destino Douro, vir a confirmar ou infirmar estas conclusões.

\section{Bibliografía}

S.n. 1953. Álbum de Portugal: repositório gráfico das suas belezas naturais, seus monumentos e grandes obras realizadas para engrandecimento nacional. (S.l.): O Século.

Bakhtin, Mikhaïl 1984. Esthétique de la création verbale. Paris: Gallimard.

Barros, Vera Gouveia 2016. Turismo em Portugal. Lisboa: Fundação Francisco Manuel dos Santos.

Barthes, Roland 1977. Escritores e Escreventes. In Ensaios Críticos. Lisboa: Edições 70, 205-215.

Bernardo, Edgar (coord.) 2018. Para um enfoque territorial do turismo no Douro. Tenerife: PASOS, Revista de Turismo y Patrimonio Cultural. Colección Edita, (n. $\left.{ }^{\circ} 21\right)$. Projeto Dourotur.

S.n., S.d.. Bird's eye view of Portugal. Lisbon: Books S.N.I.

Cabral, Oliveira S.d.. Guia turística Ilustrada (Do Minho ao Algarve). Porto: Livraria Avis.

Cadet, Christiane; Charles, René \& Galus, Jean-Luc (1990). La communication par l'image. Paris: Éditions Nathan.

Camlong, André 1984. Essai d'analyse sémiotique du sonnet VIII de Cláudio Manuel da Costa. Separata Arquivos do Centro Cultural Português. Lisboa-Paris: Fundação Calouste Gulbenkian, 115-147.

S.n. 1950. Cartilha da Terra Portuguesa. Lisboa: Edições S.N.I.

Castanheira, J. Pedro (coord.) (2009). The Best Guide Portugal: Porto, Gaia \& Douro. (S.l.): (S.n.).Edição bilingue inglês - português.

Chantal, Suzanne 1944. PORTUGAL terres et gens. Lisboa: Shell Portuguesa. Colaboração S.N.I.

Cordeiro, Maria João 2017. Olhares turísticos: Portugal em guias de viagem alemães. In Literatura, viagens e turismo cultural no Brasil, em França e em Portugal. Lisboa: Centro de Estudos Geográficos, Instituto de Geografia e Ordenamento do Território, Universidade de Lisboa, 350-361.

S.n. 2001. Dicionário da Língua Portuguesa Contemporânea da Academia das Ciências de Lisboa. Lisboa: Academia das Ciências de Lisboa; Editorial Verbo. Volume II.

Dionísio, Sant’Anna (coord.) 1977. Alto Douro Ignoto. 2. edição. Porto: Lello \& Irmão.

Dionísio, Sant'Anna (coord.) 1995a: Guia de Portugal: Trás-os-Montes e Alto Douro. Tomo I-Vila Real, Chaves e Barroso. 3. a ed. Lisboa: Fundação Calouste Gulbenkian. Volume V.

Dionísio, Sant'Anna (coord.) 1995b. Guia de Portugal: Trás-os-Montes e Alto Douro. Tomo II - Lamego, Bragança e Miranda. 3. ${ }^{a}$ ed. Lisboa: Fundação Calouste Gulbenkian. Volume V.

S.n. 2012. Douro: guia turístico do Douro. (S.1.): Turismo do Douro.

Fernandes, Didiana; Vieira, Isabel \& Rodrigues, Ana Paula 2016. A imagem turística do Alto Douro Vinhateiro: os guias de viagem da $1 .^{a}$ metade do século XIX. In Desafios, Estratégias e Tendências em Turismo e Hotelaria. Faro: Escola Superior de Educação e Comunicação, Universidade do Algarve, 217-236.

Fernandes, Didiana 2016. O Douro Vinhateiro nos guias de viagem estrangeiros dos séculos XIX e XX (1845-1974). In Atas das 4. ${ }^{a}$ s Conferências do Museu de Lamego / CITCEM-2016: Vindos de Longe. Estrangeiros no Douro, p. 75-80. Disponível em www.museudelamego.pt.

Fonseca, Joaquim 1994. Pragmática Linguística: introdução, teoria e descrição do Português. Porto: Porto Editora.

Foucault, Michel 1969. Archéologie du savoir. Paris: Gallimard.

S.n. 1990. Guia Turístico de Portugal de A a Z. 1. ${ }^{a}$ edição. Lisboa: Publicações Dom Quixote.

S.n. 1982. Guia turístico: Marão - Douro e Trás-os-Montes. Portugal: Direção-Geral do Turismo.

Joly, Martine 2009. Introduction à l'analyse de l'image. 2. édition. Paris: Armand Colin.

S.n. s.d.. Le Portugal: en un clin d'oeil. Lisbonne: Editions SNI. 
Macedo, Diogo de 1944. Terras Portuguesas: Douro - 4. (S.l.): Shell.

Agência LUSA 2007. Chefe de projecto da Estrutura de Missão para a Região Demarcada do Douro inicia funções sexta-feira. Disponível em https://www.rtp.pt/noticias/pais/chefe-de-projecto-da-estrutura-de-missao-para-a-regiao-demarcada-do-douro-inicia-funcoes-sexta-feira_n42560.

Martins, Luís 2011. Os guias de viagem, a cartografia e os fundamentos do turismo. Comunicação, $I V$ Simpósio Luso-Brasileiro de Cartografia Histórica. Porto: Faculdade de Letras da Universidade do Porto.

Mendes, João, et al. 2012. Percursos de evasão: Porto e Norte. Lisboa: DECOPROTESTE, Lda.

Moreira, José 2008. Douro: guia turístico: Douro singular, Douro universal. Porto: Educação Nacional.

Oliveira, Manuel Alves 1990. Guia Turístico de Portugal de A a Z. 1. ${ }^{a}$ edição. Lisboa: Publicações Dom Quixote.

Pinto, Arnaldo 1961. Guia turística Alfabética de Portugal Continental. Porto: Livraria Avis.

Quinteiro, Sílvia \& Baleiro, Rita 2017. Estudos em literatura e turismo: conceitos fundamentais. Lisboa: Universidade de Lisboa, Faculdade de Letras, Centro de Estudos Comparatistas. PDF.

Ribas, Tomaz 1984. Roteiro Portugal Turístico. Lisboa: Círculo dos Leitores. Apresentação de.

Romão, José; Sousa, Mónica \& Gomes, Elisa (2016). Geoturismo e enoturismo em rede: uma mais-valia para o desenvolvimento sustentável da região do Douro. In 40 Anos da Associação Portuguesa de Geólogos. PPS-PDF.

Rosas, Fernando (coord.) 1998. História de Portugal: o Estado Novo. Lisboa: Editorial Estampa.

Salvador, José A. 2010. DOURO: o Rio do Vinho. Porto: Edições Afrontamento.

Santana, Maria Olinda Rodrigues 2009a. Douro: património, vinhos, cultura, paisagem, excelência. Douro: Turismo do Douro, Estrutura de Missão do Douro, Comissão de Coordenação e Desenvolvimento Regional do Norte.

Santana, Maria Olinda Rodrigues 2009b. Patrimoine, vins, culture, paysage, pôle d'excellence. Douro: Turismo do Douro, Estrutura de Missão do Douro, Comissão de Coordenação e Desenvolvimento Regional do Norte.

Santana Talavera, Agustín 2015. Imaginando la imagem em turismo: un viaje de ida y vuelta. Revista de Antropología Experimental, n. ${ }^{\circ}$ 15, Universidad de Jaén. Monografico: Antropología del Turismo, Texto 4, 37-53.

Sarmento, J. C. V. 2004. Representação, Imaginação e Espaço Virtual: geografias de paisagens turísticas em West Cork e nos Açores. Lisboa: Fundação Calouste Gulbenkian e Fundação para a Ciência e Tecnologia.

Savelli, Luciana, et al. 2002. Porto: Norte de Portugal. Bergamo: Bonechi, Edizioni Il Turismo, S.R.L.

Tapada, Alberto 2012. DOURO: GUIA turístico da NATUREZA: paisagem, geologia, fauna, flora, turismo. (S.1.): Turismo Douro.

Tapada, Alberto 2013. ALDEIAS VINHATEIRAS DO DOURO: GUIA TURÍSTICO. (S.1.): Turismo Douro. Veloso, Pedro; Fonseca, Susana \& Fonseca, Sérgio (2010). Douro: viagens e histórias: uma viagem pelo Douro Português. 1. ${ }^{\mathrm{a}}$ edição. Maia: Objecto Anónimo. (2. ${ }^{\mathrm{a}}$ edição 2014).

S.n. 1941. Visitez Le Portugal. Lisbonne: Éditions S.P.N.

\section{Notas}

1 Este artigo foi elaborado no âmbito da linha 1 (Oferta turística) do projeto de I\& DOUROTUR - Tourism and technological innovation in the Douro, n. ${ }^{\circ}$ da operação NORTE-01-0145-FEDER-000014, cofinanciado pelo Fundo Europeu de Desenvolvimento Regional (FEDER) através do NORTE 2020 (Programa Operacional Regional do Norte 2014/2020). PT: Este trabalho é financiado por: Fundos Europeus Estruturais e de Investimento, na sua componente FEDER, através do Programa Operacional Competitividade e Internacionalização (COMPETE 2020) [Projeto n ${ }^{\circ} 006971$ (UID/SOC/04011); Referência do Financiamento: POCI-01-0145-FEDER-006971]; e por Fundos Nacionais através da FCT - Fundação para a Ciência e a Tecnologia, no âmbito do projeto UID/SOC/04011/2013.

2 Não definimos territorialmente Douro, como: rio, região demarcada e regulamentada, NUTS III, Polo de Turismo ou outras variantes, porque todas estão descritas no relatório Bernardo, Edgar (coord.) (2018): "Para um enfoque territorial do turismo no Douro". Tenerife: PASOS, Revista de Turismo y Patrimonio Cultural. Colección Edita, n. ${ }^{\circ} 21$. Projeto Dourotur. Ao longo do texto deixamos que os autores apresentassem a sua interpretação geográfica do conceito.

3 (S.n.) (1950). Cartilha da Terra Portuguesa. Lisboa: Edições S.N.I. Não aparece o nome do autor dos textos. Ocorre o nome da ilustradora (Manuela) sem apelido.

4 (S.n.) (1982). Guia turístico: Marão - Douro e Trás-os-Montes. Portugal: Direção-Geral do Turismo.

5 Segunda República de Portugal, período autoritário de 48 anos entre dois golpes de Estado: o de 28 de Maio de 1926 e o de 25 de Abril de 1974, o início da democracia (Rosas 1998).

6 O golpe de Estado do 25 de Abril de 1974 instituiu a democracia em Portugal, tendo derrubado um regime ditatorial fascista.

7 Os guias analisados publicados ou apoiados pelo SNI ostentam nas primeiras ou últimas páginas a frase: "Visado nos termos do art. 24 do Decreto 34.134 de 24-XI-1944", ou seja, visto pelos crivos da censura. 
8 Guias analisados sem autor:

(S.n.) (1941). Visitez Le Portugal. Lisbonne: Editions S.P.N.

(S.n.) (s.d.). Le Portugal: en un clin d'oeil. Lisbonne: Editions SNI. (Data provável 1944).

(S.n.) (s.d.). Bird’s eye view of Portugal. Lisbon: SNI Books. (Data provável 1944).

(S.n.) (1950). Cartilha da Terra Portuguesa. Lisboa: Edições S.N.I.

(S.n.) (1953). Álbum de Portugal: repositório gráfico das suas belezas naturais, seus monumentos e grandes obras realizadas para engrandecimento nacional. (S.l.): O Século.

9 Mentor da política cultural do regime foi diretor do SPN e SNI de 1933 a 1950.

10 Consultem-se os verbetes referentes às cidades de Lisboa e Porto em (s.n.). Le Portugal: en un clin d'oeil e Bird's eye view of Portugal, (1944). Portugal: terres et gens de Suzanne Chantal, e (1953). Álbum de Portugal: repositório gráfico das suas belezas naturais, seus monumentos e grandes obras realizadas para engrandecimento nacional, edições apoiadas pelo SNI.

11 Por exemplo, nos dois guias: (S.n.) (s.d.). Le Portugal: en un clin d'oeil. Lisbonne: Editions SNI; (S.n.) (s.d.). Bird's eye view of Portugal. Lisbon: SNI Books, no caderno de fotografias inserido entre as páginas 47 e 49 . A capa a cores é do ilustrador modernista Bernardo Marques.

12 Idem, ibidem.

13 Macedo, Diogo de (1944). Terras Portuguesas: Douro - 4. (S. L.): Shell, p. 6.

14 Cabral, Oliveira (s.d.). Guia turística Ilustrada (Do Minho ao Algarve). Porto: Livraria Avis. Pelo tipo de abordagem, pela editora, consideramos que esta obra não datada deve ter sido publicada na mesma década.

15 Pinto, Arnaldo (1961). Guia turística Alfabética de Portugal Continental. Porto: Livraria Avis.

16 Aborda a existência do mirandês.

17 Dionísio, Sant'Anna et al. (1995a). Guia de Portugal: Trás-os-Montes e Alto Douro. Tomo I-Vila Real, Chaves e Barroso. 1. ${ }^{\mathrm{a}}$ edição e 3. ${ }^{\mathrm{a}}$ edição. Lisboa: Fundação Calouste Gulbenkian. Volume V.

_ (1995b). Guia de Portugal: Trás-os-Montes e Alto Douro. Tomo II-Lamego, Bragança e Miranda. 1. a e 3. edição. Lisboa: Fundação Calouste Gulbenkian. Volume V.

18 Vigoraram até 2002.

$1925^{\mathrm{a}}$ sessão do Comité do Património Mundial, efetuada em Helsínquia [Nomeação do ADV n. ${ }^{\circ} 1046$ CPM, Helsínquia decisão 25 COM X.A].

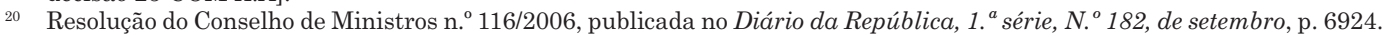

21 Entrevista de Ricardo Magalhães à RTP aquando do início das suas funções, internet: https://www.rtp.pt/noticias/pais/ chefe-de-projecto-da-estrutura-de-missao-para-a-regiao-demarcada-do-douro-inicia-funcoes-sexta-feira_n42560, (acedido em 10-11-17).

22 A Missão cessou funções, a partir de 2014, pela Resolução do Conselho de Ministros n. ${ }^{\circ} 4 / 2014$, e foi acometida à CCDR-N a missão de proteger, conservar e valorizar, bem como divulgar e promover a "Paisagem Cultural, Evolutiva e Viva do Alto Douro Vinhateiro", funções que ainda hoje assume.

23 Douro, Oeste, Litoral Alentejano, Serra da Estrela, Alqueva, Porto Santo, vigoraram até 2015.

24 (S.n.) (2012). Douro: guia turístico do Douro. (S.l.): Turismo do Douro; Tapada, Alberto (2012). DOURO: GUIA turístico da NATUREZA: paisagem, geologia, fauna. Flora, turismo. (S.l.): Turismo Douro. Textos: Alberto Tapada; fotografias vários; Tapada (2013). ALDEIAS VINHATEIRAS DO DOURO: GUIA TURÍSTICO. (S.1.): Turismo Douro. Textos: Alberto Tapada; fotografias vários.

25 Referimo-nos, em especial, aos promotores do turismo fluvial no Douro, grandes captadores de fluxos turísticos para o território.

26 Savelli, Luciana, et al. (2002). Porto: Norte de Portugal. Bergamo: Bonechi, Edizioni "Il Turismo", S.R.L. Tradução do italiano de Filipa de Sousa e Rui de Sousa; Mendes, João, et al. (2012). Percursos de evasão: Porto e Norte. 1 . $^{\mathrm{a}}$ edição. Lisboa: DECOPROTESTE, Lda.

27 Castanheira, J. Pedro et al. (2009). The Best Guide Portugal: Porto Gaia \& Douro. (S.1.): (S.n.). Edição bilingue inglês português. Textos Margarida Ramalho. Tradução inglês Bárbara Menezes Ferreira.

28 Moreira, José (2008). Douro: guia turístico: Douro singular, Douro universal. Porto: Educação Nacional; Veloso, Pedro; Fonseca, Susana \& Fonseca, Sérgio (2010). Douro: viagens e histórias: uma viagem pelo Douro Português. 1. a edição. Maia: Objecto Anónimo. (2. ${ }^{\text {a }}$ edição 2014); (S. n.) (2012). DOURO: GUIA TURÍSTICO DO DOURO. (S.l.): Turismo Douro. Sem autor; fotografias vários; Tapada, Alberto (2012). DOURO: GUIA turístico da NATUREZA: paisagem, geologia, fauna. Flora, turismo. (S.1.): Turismo Douro. Textos: Alberto Tapada; fotografias vários; Tapada, Alberto (2013). ALDEIAS VINHATEIRAS DO DOURO: GUIA TURÍSTICO. (S.l.): Turismo Douro. Textos: Alberto Tapada; fotografias vários.

29 Nas informações práticas fornece os principais alojamentos, com destaque para as quintas que praticam enoturismo, a restauração, os postos de turismo, adegas, e vários circuitos à escolha do turista, acompanhados pelos mapas necessários.

30 Do texto introdutório de António Martinho, Presidente da Entidade Regional de Turismo do Douro.

31 Tapada, Alberto (2013). Ibidem. Vila Real: Turismo do Douro.

32 Barcos "AAfirmação Municipalista"; Favaios "Em nome do pão ...e do vinho!"; Provesende "A notável”; Salzedas "O lugar onde o tempo medita!"; Trevões "Secular fortaleza moral!"; Ucanha "A Incontornável linha do tempo".

Recibido:

$03 / 04 / 2018$

Reenviado: 